Check for updates

Cite this: Metallomics, 2020, 12, 1278

Received 16th April 2020, Accepted 12th June 2020 DOI: 10.1039/d0mt00099j

rsc.li/metallomics

\section{Uptake, translocation and accumulation of nickel and cobalt in Berkheya coddii, a 'metal crop' from South Africa $\uparrow$}

\author{
Marie Rue, ${ }^{\text {ab }}$ Adrian L. D. Paul, ${ }^{c}$ Guillaume Echevarria, ${ }^{\text {ac }}$ Antony van der Ent, (D) ${ }^{\text {ac }}$ \\ Marie-Odile Simonnot (DD ${ }^{* b}$ and Jean Louis Morel ${ }^{a}$
}

\begin{abstract}
Hyperaccumulator plants have the ability to efficiently concentrate metallic elements, e.g. nickel, from low-grade sources into their living biomass. Although the majority of nickel hyperaccumulator plant species restrict cobalt uptake, some species are able to co-accumulate cobalt when growing in ultramafic soils. The asteraceous perennial herb Berkheya coddii from South Africa is one of the most promising agromining crops known globally. It may accumulate nickel in excess of $30000 \mu \mathrm{g} \mathrm{g}^{-1}$ in dry leaves, while co-accumulating up to $600 \mu \mathrm{g} \mathrm{g}^{-1}$ cobalt. This study aimed to elucidate the interactions between nickel and cobalt for uptake by and translocation into $B$. coddii through a pot experiment including various cobalt/nickel treatment combinations in soil, after which uptake and localisation were recorded. Cobalt in the substrate limits nickel uptake by $B$. coddii plants and is mainly retained in the basal leaves in contrast to $\mathrm{Ni}$ that is rapidly transferred to the top of the plant. $B$. coddii was more tolerant to high $\mathrm{Ni}$ concentration, whether in the substrate or internally but remains a promising crop which could be used, with suitable agronomic measures and practices, for cobalt agromining in areas with high soil cobalt but low soil nickel. A yield of $77 \mathrm{~kg} \mathrm{ha}^{-1}$ nickel and $16.5 \mathrm{~kg} \mathrm{ha}^{-1}$ cobalt may be attainable under optimum conditions.
\end{abstract}

Significance to metallomics

The hyperaccumulator plant Berkheya coddii from South Africa is one of the most promising 'agromining crops' known globally. This article reports on the interactions between cobalt and nickel for uptake and translocation in this species. Cobalt in the substrate inhibits nickel uptake in plants, and while nickel is rapidly transferred to the top of the plant, cobalt is mainly retained in the basal leaves.

\section{Introduction}

Hyperaccumulators are plants that accumulate metal and metalloid trace elements to extraordinarily high concentrations in their living biomass. ${ }^{1-4}$ The phenomenon is known to occur across many different phylogenetic lineages around the world. Hence it has evolved independently multiple times. ${ }^{2,5}$ Remediation of metal-contaminated soils was the first application ever considered for phytotechnologies based on hyperaccumulator plants. ${ }^{6,7}$ The concept of phytomining involves the

\footnotetext{
${ }^{a}$ Université de Lorraine, INRAE, LSE, F-54000 Nancy, France

${ }^{b}$ Université de Lorraine, CNRS, LRGP, F-54000 Nancy, France.

E-mail: marie-odile.simonnot@univ-lorraine.fr

${ }^{c}$ Centre for Mined Land Rehabilitation, Sustainable Minerals Institute,

The University of Queensland, Australia

$\dagger$ Electronic supplementary information (ESI) available. See DOI: 10.1039/d0mt00099j
}

agronomic cultivation of hyperaccumulator plants (or 'metal crops') to produce metal-rich biomass which can be processed with hydro- or pyrometallurgy to make crude metal or pure salt products. $^{8-12}$ The production of compounds based on metals extracted from plants is based on the possibility of cultivating these plants on a large-scale, which implies the implementation of agronomic processes. Agromining is a newly developed industry sector that takes metal extraction by plants through to the production of value-added compounds. It has many advantages as it allows: (i) recovery of metals disseminated in secondary resources that cannot be exploited by conventional methods; (ii) detoxification of soils or minerals wastes by a progressive lowering of the metal content; and (iii) generation of energy during the incineration of the biomass and the reuse of by-products as fertilisers. To be viable (obtain high yields of target metals), it is necessary to select plants not only with a high capability for hyperaccumulation but also having 
favourable growth characteristics including high biomass. ${ }^{12-14}$ A recent analysis of the life cycle of agromining showed that environmental impacts were presumably low. ${ }^{15,16}$ Furthermore, agromining meets the concept of sustainable development, in environmental, economic and sociological terms, as it provides income to farmers in disadvantaged regions with agronomically poor soils (mostly ultramafic).

More than two-third of the discovered hyperaccumulators $(\sim 500)$ accumulate $\mathrm{Ni}\left(>1000 \mu \mathrm{g} \mathrm{g}^{-1}\right.$ foliar d.w.) as a result of ultramafic soils preponderance and the ease to test $\mathrm{Ni}$ hyperaccumulation in the field. ${ }^{17}$ It resulted in a considerable scientific effort including the use of state-of-the-art technologies (e.g. synchrotron micro-XRF) to understand the underlying mechanisms leading to this Ni-hyperaccumulation and the occurrence of even more extreme phenomenon such as the green phloem tissues with exceptionally high concentrations of Ni observed in several plants endemic to southeast Asia (e.g. Rinorea aff. bengalensis, R. aff. Javanica or Dichapetalum gelonioides subsp. tuberculatum) ${ }^{18-20}$ In comparison to Ni-hyperaccumulator plants, cobalt (Co)-hyperaccumulator plants have been relatively little studied. Hyperaccumulation of Co was first defined as $>1000 \mu \mathrm{g} \mathrm{g}^{-1}$ foliar d.w. Co but later revised downwards to $>300 \mu \mathrm{g} \mathrm{g}^{-1}$ foliar d.w. ${ }^{4,21,22}$ About 40 taxa scattered in $\sim 20$ families mostly found in the south-eastern D.R. Congo growing on Co-enriched soils have been reported to hyperaccumulate Co. ${ }^{23,24}$ The highest known Co-accumulator, Haumaniastrum robertii (Lamiaceae) from the Democratic Republic of Congo, was discovered in the 70s and demonstrates concentrations $\sim 10000 \mu \mathrm{g} \mathrm{g}^{-1}$ Co in leaves. ${ }^{21}$ These extreme foliar concentrations raised doubts about possible soil particle contamination and remained until synchrotron X-ray absorption spectroscopy analysis proved endogenous $\mathrm{Cu}-\mathrm{Co}$ (hyper)accumulation in Haumaniastrum katangense. ${ }^{25}$ High foliar Co levels have also been reported in Glochidion $c f$. sericeum (Phyllanthaceae), Rinorea javanica and Rinorea bengalensis (Violaceae) with foliar concentrations respectively up to $1310 \mu \mathrm{g} \mathrm{g}^{-1}, 670 \mu \mathrm{g} \mathrm{\textrm {g } ^ { - 1 }}$ and $545 \mu \mathrm{g} \mathrm{g}^{-1}$ in their natural environment while Alyssum troodii (Brassicaceae) demonstrated extreme concentrations reaching up to $2325 \mu \mathrm{g} \mathrm{g}^{-1}$ when growing in a Co-spiked artificial rooting media. ${ }^{20,26,27}$

Globally, the presence of Co and Ni in soils is the result of rock weathering and anthropogenic activities. ${ }^{28}$ They may be found in association at high concentrations (e.g. South-Africa, Sabah, Albania) and are closely related geochemically (their atomic weights differ by $<0.5 \%-58.69 \mathrm{u}$ and $58.93 \mathrm{u}$ respectively). ${ }^{20,28-30}$ They are both transition metals often found in association and typically in $2+$ oxidation state. They also are more mobilised at low $\mathrm{pH}$ but while this is true under reducing conditions for $\mathrm{Co}$, it is under oxidising conditions for $\mathrm{Ni}^{30}$ Additionally, both can co-precipitate with Fe/Mn hydroxides or clays minerals and be complexed by organic matter. ${ }^{30}$ Consequently, some Ni hyperaccumulator plants may also accumulate Co. ${ }^{20,31}$ The Ni hyperaccumulators Alyssum murale and corsicum can accumulate $>1000 \mu \mathrm{g} \mathrm{g}^{-1}$ Co in the absence of $\mathrm{Ni}^{31}$ In hyperaccumulator plants, both elements compete for the same root transporters and intercellular ligands resulting in lower uptakes for both elements but more intense for $\mathrm{Ni}^{.32-34}$ In A. troodii the presence of $\mathrm{Co}$ and $\mathrm{Ni}$ at the same concentration decreases the uptake of Ni by more than ten-fold compared to a substrate without $\mathrm{Co}^{27}$ Both A. murale and corsicum, in muck and silt soils heavily contaminated in Ni via particulate emissions, had the particularity to uptake more $\mathrm{Ni}$ as soil $\mathrm{pH}$ increased despite the $\mathrm{Ni}$ water-soluble concentrations decrease. ${ }^{35,36}$ This phenomenon was not observed for Co suggesting the existence of distinct uptake patterns despite clear elemental interactions.

Among the best-studied nickel (Ni) hyperaccumulators globally, Berkheya coddii, an herbaceous perennial species (Family: Asteraceae) endemic to the Mpumalanga Province of South Africa can accumulate up to $36000 \mu \mathrm{g} \mathrm{g}^{-1} \mathrm{Ni}$ in the field and up to $76000 \mu \mathrm{g} \mathrm{g}^{-1} \mathrm{Ni}$ in culture and achieve a yield of $22 \mathrm{t} \mathrm{ha}^{-1}$ per harvest. ${ }^{6,28,37-40}$ In $B$. coddii, in contrast to many other species, at the adult stage, $\mathrm{Ni}$ is strongly enriched in the leaf veins and mesophyll. In contrast, the Ni concentrations in the epidermis, where $\mathrm{Ni}$ is stored in most hyperaccumulator plants, are relatively low. ${ }^{31,41-44}$ Cobalt hyperaccumulation in $B$. coddii has predominantly been observed experimentally and in the absence of $\mathrm{Ni}^{31,32}$ However, it may hyperaccumulate $600 \mu \mathrm{g} \mathrm{g}^{-1}$ of Co in the wild under specific conditions resulting in a higher soluble Co: Ni ratio (e.g. in waterlogged soils). ${ }^{34}$

This study aimed to elucidate the interactions between $\mathrm{Ni}$ and Co for uptake and translocation into $B$. coddii when the plant completes its full phenological cycle. Therefore, to understand the physiological consequences of the competition between the two elements, a long-term pot experiment with sufficient volumes of controlled soil samples amended with different Co: Ni ratios at low or high concentrations was done. The understanding of the physiological trade-off between the two metals by this potential agromining crop aimed at helping to formulate further hypotheses on the mechanisms involved in the uptake of both metals by the plant.

\section{Materials and methods}

\section{Soil collection}

Soil samples were collected from the Ap horizon of a Cambisol developed on Jurassic marls in north-eastern France (experimental farm of "La Bouzule"), under wheat cultivation. The soil was chosen because of its characteristics that were believed to represent optimal growth conditions (history of fertilisation) and equilibrated soil texture, without any significant available contents of neither $\mathrm{Co}$ or $\mathrm{Ni}$, as well as a low carbon content. The choice for this soil also relied on relatively moderate sorption properties to avoid metal scavenging that would prevent from seeing any effect of competition for root uptake.

\section{Chemical and physical analysis of soil material samples}

The pH was measured according to the NF ISO 10390 method: $1 / 5$ (volume fraction) suspension of soil in water was shaken for $1 \mathrm{~h} 20 \mathrm{~min}$ and left to stand for one additional hour before measurement. Samples were then centrifuged and filtered 
through $0.45 \mu \mathrm{m}$ membranes for CEC. Organic C and total $\mathrm{N}$ were measured with CHNS (vario MICRO cube, Elementar) following the NF ISO 10694 et 13878 methods. Available Phosphorus was determined through the Olsen NF ISO 11263 method. Extraction via diethylenetriamine pentaacetate (DTPA) was performed using the method NF X 31-121 (solid/liquid ratio $(\mathrm{m} / \mathrm{v})$ of $1 / 2$ at $\mathrm{pH} 7.3)$ to determine phytoavailable concentrations. ${ }^{44}$ To determine pseudo-total elemental concentrations, soil samples $(\sim 500 \mathrm{mg})$ were digested (NF ISO 11466 standard) with $2 \mathrm{~mL} 70 \% \mathrm{HNO}_{3}$ and $6 \mathrm{~mL} 37 \% \mathrm{HCl}$ per sample using heating block (DigiPREP, SCP Science) programmed to maintain a temperature of $105{ }^{\circ} \mathrm{C}$ for $120 \mathrm{~min}$ and diluted with ultrapure water before analysis. All digests and extracts were analysed using inductively coupled plasma atomic emission spectroscopy (ICP-OES spectrometry-Thermo Fischer iCAP $6300 \mathrm{Duo}$ ) for $\mathrm{Al}, \mathrm{Ca}, \mathrm{Co}, \mathrm{Cr}, \mathrm{Cu}, \mathrm{Fe}, \mathrm{K}, \mathrm{Mg}, \mathrm{Mn}, \mathrm{Mo}, \mathrm{Ni}, \mathrm{Ni}, \mathrm{P}$ and $\mathrm{Zn}$. All analyses were carried out by the laboratoire d'analyse des sols (INRA-Arras, France). Initial total and extractable soil element concentrations and general properties of the Cambisol used in the experiment are shown in Table S1 (ESI $\dagger$ ).

\section{Plant dosing treatments}

The soil was sieved at $1 \mathrm{~cm}$, and 12 pots were filled with $15 \mathrm{~kg}$ of soil each to ensure a sufficient development of the plants up to flowering stages. The spiking solutions were prepared by dissolving the appropriate amounts of $\mathrm{Ni}$ and Co salts $\left(\mathrm{Ni}\left(\mathrm{NO}_{3}\right)_{2} \cdot 6 \mathrm{H}_{2} \mathrm{O}\right.$ and $\mathrm{Co}\left(\mathrm{NO}_{3}\right)_{2} \cdot 6 \mathrm{H}_{2} \mathrm{O}$ (Extra pure, SLR, Fisher Chemical)) in $0.6 \mathrm{~L}$ of ultrapure water; this volume was chosen to correspond to $80 \%$ of the field capacity. Thus, the concentrations of the solutions were: 1.032 and $10.32 \mathrm{~g} \mathrm{~L}^{-1}$ of Ni salt to reach respectively 10 and $100 \mathrm{mg}$ of $\mathrm{Ni}$ per kg of dry soil, and 1.029 and 10.29 of Co salt to reach respectively 10 and $100 \mathrm{mg}$ of Co per kg of dry soil. Four modalities were prepared to reach four $\mathrm{Ni}$ : Co ratios in the following treatments: Ni100Co100 (100 mg kg $\left.{ }^{-1} \mathrm{Ni}+100 \mathrm{mg} \mathrm{kg}{ }^{-1} \mathrm{Co}\right)$, Ni100Co10 (100 mg kg ${ }^{-1}$ $\left.\mathrm{Ni}+10 \mathrm{mg} \mathrm{kg}^{-1} \mathrm{Co}\right)$, Ni10Co100 (10 mg kg ${ }^{-1} \mathrm{Ni}+100 \mathrm{mg} \mathrm{kg}^{-1}$ Co), and Ni10Co10 (10 mg kg $\left.{ }^{-1} \mathrm{Ni}+10 \mathrm{mg} \mathrm{kg}{ }^{-1} \mathrm{Co}\right)$. Each treatment was prepared in triplicate; therefore, 12 pots were set up. No fertilisation was provided. Thus, $95.3 \mathrm{mg}$ of $\mathrm{N}$ per $\mathrm{kg}$ of dry soil for the Ni100Co100 modality, $52.5 \mathrm{mg} \mathrm{kg}^{-1}$ for the Ni10Co100 and Ni100Co10 modalities and $9.53 \mathrm{mg} \mathrm{kg}^{-1}$ for the Ni10Co10 modality.

\section{Propagation and plant culture}

Seeds of B. coddii were collected in the Queen's River Valley near Barberton, South Africa. Twelve seeds were sown per pot in six places. One month after germination, six seedlings were left in each pot. If necessary, transplantation was made between two pots from the same modality. An automatic watering was set up with tap water to maintain the water holding capacity of the soil at $80 \%$ (Table S2, ESI $\dagger$ ). Pots were placed in a growth chamber with the following conditions: $16 \mathrm{~h}$ light cycle with the temperature maintained at $25{ }^{\circ} \mathrm{C}$ during the day and $19{ }^{\circ} \mathrm{C}$ during the night, $50 \%$ relative humidity and a photosynthetic photon flux density of $350 \mathrm{mmol} \mathrm{m} \mathrm{m}^{-2} \mathrm{~s}^{-1}$.

\section{Harvest of plants}

The harvest period and methodology are detailed in Table S2 (ESI $\dagger$ ). The first batch of harvests was carried out for individual plants showing a wilted primary floral bud, i.e. the first to bloom (corresponding to the one located at the apex of the main stem). This harvesting only concerns stems and leaves. All plants, including the plants previously sampled, were then harvested a second time after 14 months at the end of the experiment ( $2^{\text {nd }}$ harvest). The morphology of plants collected at the first harvest was characterised by the number and length of leaves, the diameter and length of stems. Elemental composition of the different organs was also determined (Fig. S1, ESI $\dagger$ ). At first harvest, all plant parts were separated (leaves, stems and capitula, if any). For each group of floral buds, the inflorescence parts were separated as follows: bracts, receptacle, disk florets, ray florets and seeds (Fig. S2, ESI $\dagger$ ). The disk and ray florets were not washed to retain the pollen. Roots were extracted from each pot, separated into four parts (tuber, medium, small and fine roots), and washed with ultrapure water (Fig. S3, ESI $\dagger$ ). The tubers were cleaned gently with a brush when necessary. At the second harvest, the aerial parts were not separated, and all above-ground parts were pooled (stems, leaves and capitula, if any).

\section{Plant analysis, chemical bulk analysis of tissue samples}

Fresh plant samples were weighed, washed with ultrapure water and dried at $50{ }^{\circ} \mathrm{C}$ for $48 \mathrm{~h}$. All dried plant samples were ground and digested using $5 \mathrm{~mL} \mathrm{HNO}_{3}(65 \%)$ and $2 \mathrm{~mL} \mathrm{H}_{2} \mathrm{O}_{2}$ (30\%). After $16 \mathrm{~h}$, samples were placed in a DigiPREP ${ }^{\mathbb{R}}$ system (SCP Science, Baie-d'Urfé, QC, Canada) for $120 \mathrm{~min}$ at $95{ }^{\circ} \mathrm{C}$ and the resulting solutions were diluted to $25 \mathrm{~mL}$ with ultrapure water (Millipore $18.2 \mathrm{M} \Omega \mathrm{cm}$ at $25{ }^{\circ} \mathrm{C}$ ) and filtered at $0.45 \mu \mathrm{m}$ before analysis by ICP-AES (Thermo Fisher iCAP 6300 Duo) with dual configuration (axial and radial) for $\mathrm{Ca}, \mathrm{Co}, \mathrm{Cr}, \mathrm{Cu}, \mathrm{Fe}, \mathrm{K}$, $\mathrm{Mg}, \mathrm{Mn}, \mathrm{Na}, \mathrm{Ni}, \mathrm{P}, \mathrm{S}$, Zn. The PlasmaCAL multi-element solutions in $5 \% \mathrm{HNO}_{3}$ was used (SCP Science). The detection and quantification limit were calculated based on the IUPAC definition. ${ }^{45}$

\section{Statistical analyses}

For the first harvest, plant parts were separated and analysed separately but the results were ultimately merged when needed for figures and statistics. Statistical analyses were conducted with the $\mathrm{R}$ software, version 3.1 .2 (2014-10-31). Under R, possible outliers were identified by the Dixon test, the outlier package. When the data followed a normal distribution (Shapiro test) and were homoscedastic (Levene test), a parametric test (Waller-Duncan K-ratio $t$-test) was applied. If the data did not meet both criteria, they were transformed to log values in order to meet the conditions of application of the parametric tests. If the data after transformation still did not follow a normal distribution and/or were not homoscedastic, a non-parametric test (Kruskal-Wallis) was run, then a post hoc test using the FDR method. 


\section{Results}

\section{Biomass production of $B$. coddii in the treatments}

The leaves had a characteristic interveinal chlorosis in all treatments (Fig. S4, ESI $\dagger$ ). However, differences were observed as chlorosis seems more prominent in high concentration treatment compared to Ni10Co10 treatment. At low Ni/high Co concentrations, (Ni10Co100 treatment), the entire blade was chlorotic, including the ribs in contrast to other treatments for which leaf yellowing remained partial. However, no necrosis was observed in the high Co treatments or very little, unlike in Ni10Co10, Ni100Co10. The following biomass and morphological parameters varied according to the treatments: overall size of an individual, number of leaves, the lower diameter of stems, number of capitulum buds (Table 1). Despite the absence of a statistical difference, treatments with a $\mathrm{Ni}$ : Co ratio of 1 appeared to have a greater biomass and height at harvest $(>18 \mathrm{~g}$ and $\sim 145 \mathrm{~cm}$ ) than treatments with an unbalanced ratio $(<15 \mathrm{~g}$ and $\sim 128 \mathrm{~cm})$. However, statistical differences between treatments were found for the number of capitulum buds as plants from the Ni10Co100 and Ni100Co100 treatments had respectively 13.3 and 15.3 buds in average compared to Ni100Co10 (4.83 buds). As a consequence, the Ni100Co100 treatment had a significantly higher floral biomass in comparison to other treatments (Table S3, ESI $\dagger$ ). No significant differences between treatments was observed for the following parameters: stem lower and upper diameter, number of leaves, stem biomass and leaf biomass (Table S3, ESI $\dagger$ ).

\section{Nickel and cobalt concentrations in $B$. coddii aboveground parts}

The aboveground $\mathrm{Ni}$ and Co concentrations in $B$. coddii are given in Table 1. Nickel concentration in the aboveground parts differed significantly between treatments. The highest $\mathrm{Ni}$ concentration was recorded in the Ni100Co10 treatment (4540 $\mu \mathrm{g} \mathrm{g}^{-1} \mathrm{Ni}$ ) and the lowest in the Ni10Co100 treatment $\left(80.5 \mu \mathrm{g} \mathrm{g}^{-1} \mathrm{Ni}\right)$. However, Ni concentrations were found similar in the Ni100Co100 and Ni10Co10 treatments. Similarly, Co concentrations were significantly higher in the high Co treatments with values up to $770 \mu \mathrm{g} \mathrm{g}^{-1}$ in Ni10Co100 and up to $745 \mu \mathrm{g} \mathrm{g}^{-1}$ in Ni100Co100 treatments. On the contrary, aboveground Co concentrations in plots from low Co treatments were negligible with values ranging between $\sim 7$ and $\sim 70 \mu \mathrm{g} \mathrm{g}^{-1} \mathrm{Ni}$.

\section{Nickel and cobalt concentrations in $B$. coddii organs}

The organ $\mathrm{Ni}$ and Co concentrations in $B$. coddii are given in Table 2. Cobalt and Ni concentrations were the highest in the leaves and the lowest in the stems. In stems and inflorescences, $\mathrm{Ni}$ concentration decreased according to the following order: Ni100Co10 > Ni100Co100 > Ni10Co10 > Ni10Co100 treatments, while an exception was found, as the leaves contained statistically similar Ni concentrations in Ni100Co100 and Ni10Co10. In leaves, $\mathrm{Ni}$ concentrations reached concentrations up to $9730 \mu \mathrm{g} \mathrm{g}^{-1}$ in Ni100Co10, $1440 \mu \mathrm{g} \mathrm{g}^{-1}$ in Ni100Co100, $961 \mu \mathrm{g} \mathrm{g}^{-1}$ in Ni10Co10, and $197 \mu \mathrm{g} \mathrm{g}^{-1}$ in Ni10Co100 treatments. In stem, the average value ranged from $888 \mu \mathrm{g} \mathrm{g}^{-1}$ in Ni100Co10 to $40.4 \mu \mathrm{g} \mathrm{g}^{-1}$ in Ni10Co100. As of capitula, the concentration averaged 2810, 633, 336 and $87.2 \mu \mathrm{g} \mathrm{g}{ }^{-1}$ in respectively Ni100Co10, Ni100Co100, Ni10Co10 and Ni10Co100. In the opposite, Co concentrations were statistically divided in two groups for each organ with high concentrations in the Ni10Co100 and Ni100Co100 treatments and low concentrations in the Ni100Co10 and Ni10Co10 treatments. The Co leaf concentrations reached $>2000 \mu \mathrm{g} \mathrm{g}^{-1}$ in high Co treatments and were one order of magnitude greater than in low Co treatments $\left(<160 \mu \mathrm{g} \mathrm{g}^{-1}\right)$. Concentrations of Co in capitula were greater than in stems but remained very low in comparison to leaves with mean values ranging from $\sim 200 \mu \mathrm{g} \mathrm{g}^{-1}$ in high Co treatments to $\sim 10 \mu \mathrm{g} \mathrm{g}^{-1}$ in low Co treatments. As a result, the highest Ni: Co ratio was found in Ni100Co10 (77.8) and Ni10Co10 (13.3) while the ratio in high Co treatments were remarkably lower (1.13 in Ni100Co100 and 0.13 in Ni10Co100).

Globally, Ni and Co were not distributed uniformly in the plant organs, as shown in Fig. 1-3. Basal leaves were enriched in Co in low Co treatments but not in Ni, no difference could be observed in the stem but significant ones were observed among inflorescences parts i.e. the bracts, receptacles, disk and ray florets, as well as the seeds exhibited different concentrations of $\mathrm{Ni}$ and Co. The highest concentrations were recorded in the bracts for $\mathrm{Co}$ and $\mathrm{Ni}$. As the lowest concentrations, they were found in disk and ray florets, with intermediate values in the receptacles and seeds for Ni while Co concentrations were all similar in the four inflorescence parts. Nickel concentrations in the seeds increased, however this was not statistically significant, during maturation in the Ni100Co10 treatment. It was $1850 \mu \mathrm{g} \mathrm{g}^{-1}$ $\mathrm{Ni}$ in the seeds from the open capitula and $3130 \mu \mathrm{g} \mathrm{g}^{-1}$ in seeds of the wilted capitula (Table S4, ESI $\dagger$ ).

An elemental concentration gradient was determined in function of the position of the leaves on the stem (Fig. S5, $\mathrm{ESI} \dagger$ ). Basal leaves have the highest concentrations of $\mathrm{Na}, \mathrm{K}, \mathrm{B}$ and $\mathrm{Ca}$ (and biomass) compared to upper leaves (apical leaves and leaves on branches of primary stem) where $\mathrm{Cu}$ and $\mathrm{Mn}$ concentrations tend to be higher. A similar phenomenon was observed in the stems, however, not statistically significant

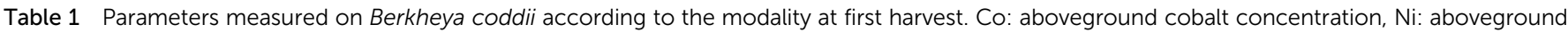

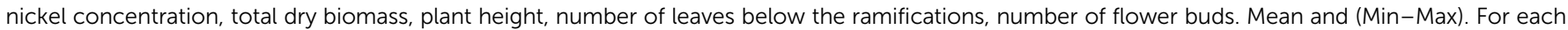
variable, the affected modalities of the same letter are not significantly different (Waller-Duncan means separation test, $p<0.05$ )

\begin{tabular}{|c|c|c|c|c|c|c|c|c|c|c|c|c|}
\hline & $\mathrm{Co}\left(\mathrm{mg} \mathrm{kg}{ }^{-1}\right)$ & & $\mathrm{Ni}\left(\mathrm{mg} \mathrm{kg}{ }^{-1}\right)$ & & Tot. Biomass & & Height $(\mathrm{cm})$ & & Nb leaves & & $\mathrm{Nb}$ buds & \\
\hline i10 & 26.9 & $b$ & $202-455)$ & $D$ & $18.2(10$. & $a$ & $146(11$ & $u$ & 1) & $a$ & 9.33 & $a b$ \\
\hline Ni100Co10 & $44.9(21.3-72.6)$ & $b$ & $3490(2210-4540)$ & $a$ & $12.6(6.8-21.7)$ & $a$ & $128(92-153)$ & $a$ & $33.3(24-38)$ & $a$ & $4.83(3-10)$ & $b$ \\
\hline Ni10Co100 & $742(716-770)$ & $a$ & $96.6(80.5-118)$ & $c$ & $14.4(12.4-17.3)$ & $a$ & $128(101-154)$ & $a$ & $35.7(31-44)$ & $a$ & $13.3(12-15)$ & $a$ \\
\hline Ni100Co100 & $511(214-745)$ & $a$ & $578(293-758)$ & $b$ & $21.7(17.7-26.5)$ & $a$ & $147(142-155)$ & $a$ & $41.0(28-51)$ & $a$ & $15.3(11-20)$ & $a$ \\
\hline
\end{tabular}


Table 2 Cobalt and nickel concentration in Berkheya coddii stem, leaves and inflorescences according to the modality. Mean and (Min-Max). For each variable, the affected modalities of the same letter are not significantly different (Waller-Duncan means separation test, $p<0.05$ )

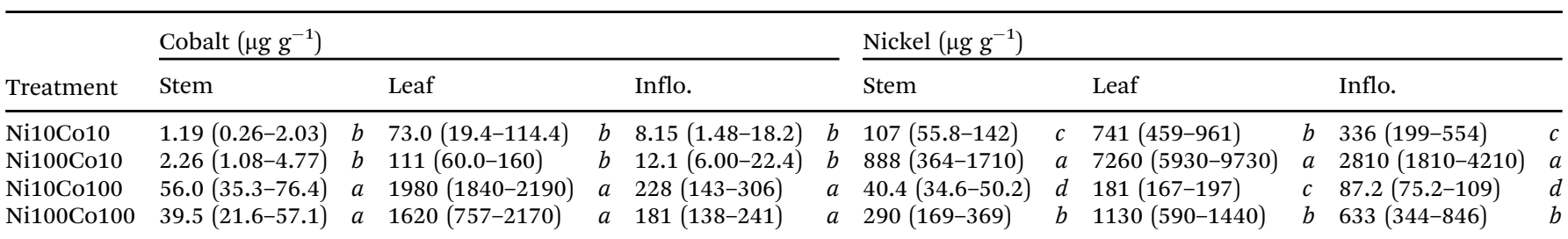
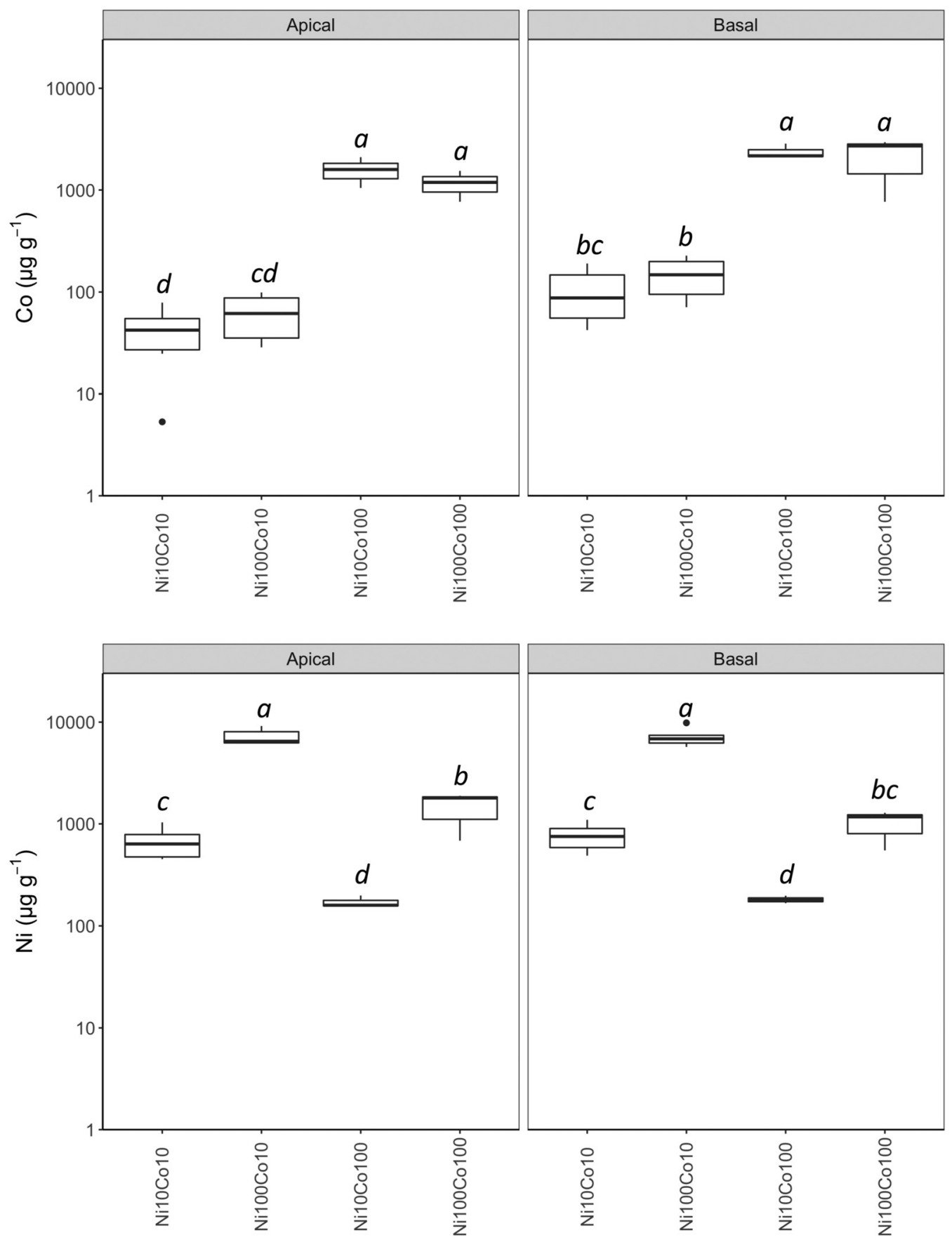

Fig. 1 Concentrations of $\mathrm{Co}$ and $\mathrm{Ni}$ in the apical and basal leaves of Berkheya coddii according to the substrate. Concentrations in $\mu \mathrm{g} \mathrm{g}^{-1}$. 

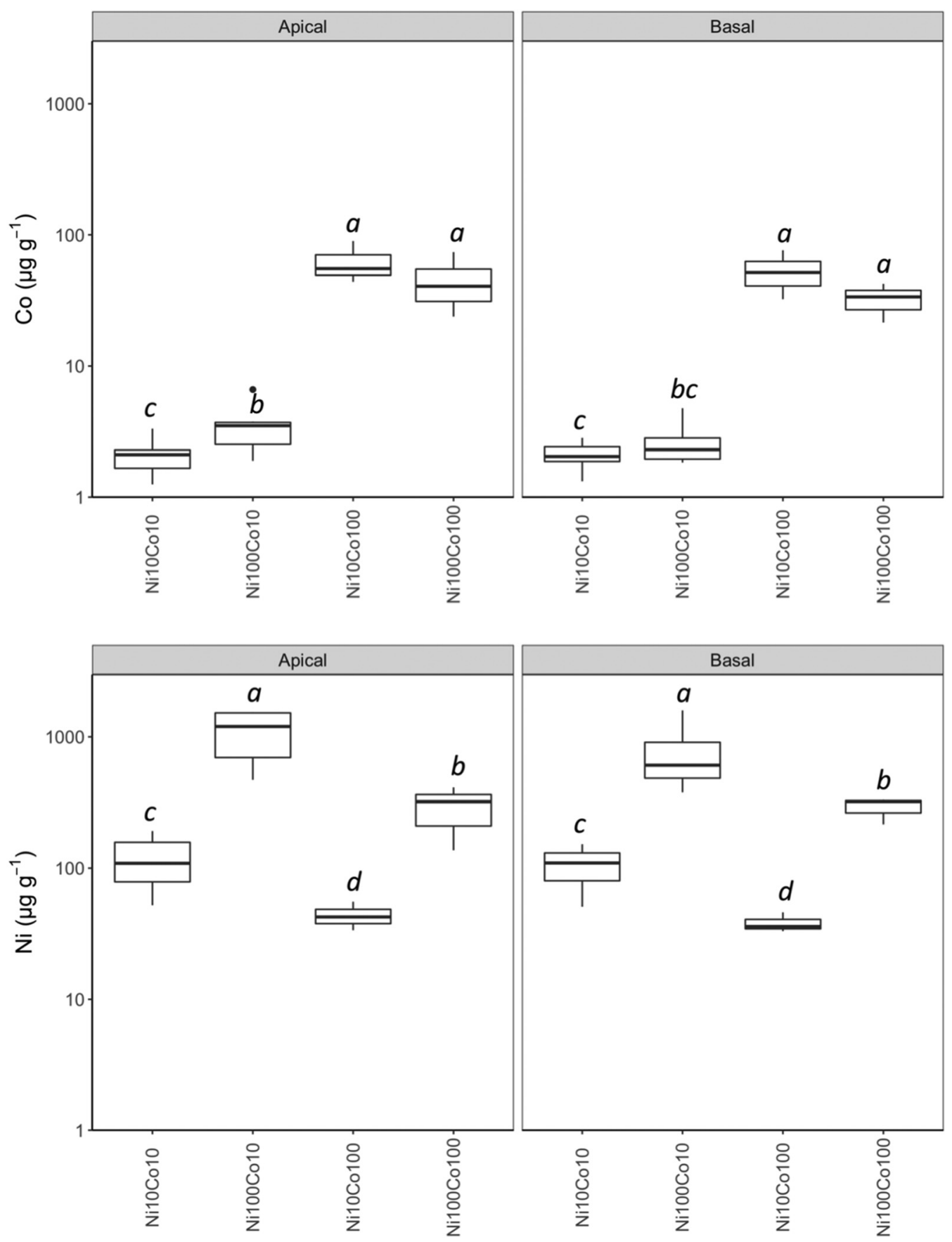

Fig. 2 Concentrations of $\mathrm{Co}$ and $\mathrm{Ni}$ in the apical and basal parts of Berkheya coddii stems according to the substrate. Concentrations in $\mu \mathrm{g} \mathrm{g}^{-1}$.

(Fig. S5, ESI $\dagger$ ). Phosphorus, $\mathrm{Cu}, \mathrm{K}$ and Fe concentrations were higher at the top of the stem while $\mathrm{Mn}, \mathrm{Na}, \mathrm{Zn}, \mathrm{Cd}, \mathrm{Mg}$ and Ca seem to be preferentially stored at the base of the stem. Regarding the whole plant elemental concentrations, the Ni100Co10 and Ni10Co10 treatments were similar in composition, with higher concentrations of $\mathrm{Ni}, \mathrm{Zn}, \mathrm{Mg}, \mathrm{P}, \mathrm{Cd}, \mathrm{K}$ than those in the Ni100Co100 and Ni10Co100 treatments (Fig. S6, ESI $\dagger$ ). The latter were characterized by high concentrations of $\mathrm{Co}, \mathrm{S}, \mathrm{Ca}$ and $\mathrm{Fe}$ and had a higher number of young capitula than in the other two treatments.
Only two pots of the Ni100Co100 treatment had living plants after 14 months. Concentration of Ni were higher in the second harvest in all treatments while mixed results were observed in regard to Co (Table 3). The Ni concentrations in the roots were higher than Co concentrations for all treatments, with the exception of Ni10Co100 for which concentrations of Co and $\mathrm{Ni}$ were similar. Cobalt concentrations were $<5 \mu \mathrm{g} \mathrm{g}^{-1}$ in the low Co treatments in roots while $<50 \mu \mathrm{g} \mathrm{g}^{-1}$ in high Co treatments. Nickel concentrations seem to vary according to the root size; apparent greater concentrations were obtained in 

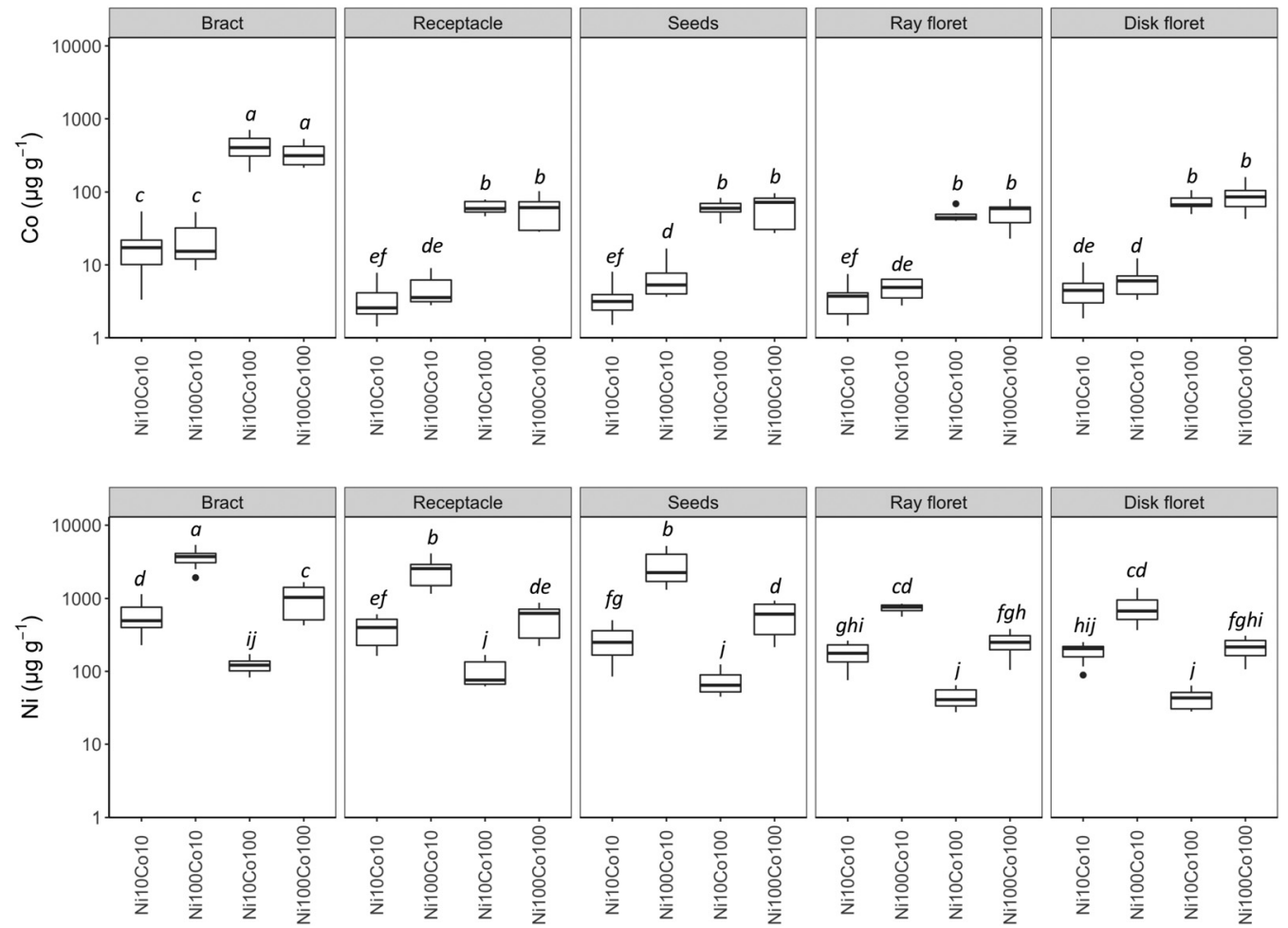

Fig. 3 Concentration of $\mathrm{Co}$ and $\mathrm{Ni}$ in floral parts of Berkheya coddii, five inflorescence parts: bract, receptacle, seeds, disk floret and ray floret according to the substrate. Concentrations in $\mu \mathrm{g} \mathrm{g}^{-1}$.

Table 3 Comparison of yields between the $1^{\text {st }}$ and $2^{\text {nd }}$ harvests of Berkheya coddii. $\mathrm{C} 1: 1^{\text {st }}$ harvest, $\mathrm{C} 2: 2^{\text {nd }}$ harvest

\begin{tabular}{|c|c|c|c|c|c|c|c|c|}
\hline Treatment & Age $\mathrm{C} 2 / \mathrm{C} 1$ & & Biom. C2/C1 & & $\mathrm{Ni} \mathrm{C} 2 / \mathrm{C} 1$ & & Co $\mathrm{C} 2 / \mathrm{C} 1$ & \\
\hline Ni100Co10 & $1.12(0.77-1.45)$ & $a$ & $1.08(0.25-2.33)$ & $a$ & $1.08(0.81-1.50)$ & $b$ & $0.44(0.23-0.64)$ & $b$ \\
\hline
\end{tabular}

the tuber; lower values were found in the middle roots and the lowest were found in the small roots. However, no statistical difference was obtained. For Co, concentrations were similar between root parts (exception of small roots $v s$. tuberous roots in the high Co treatments) (Fig. 4).

\section{Comparison of the yields of $B$. coddii in two croppings during} a 14-month cycle

Individuals that had been harvested at flowering were harvested again at the end of the experiment, 14 months after the first sowing (Table 3). The growth period of the individuals varied between the two cuts as in 9 out of 15 pots, the growth period was longer after the first harvest. In the Ni10Co10 treatment, the biomass was often lower at the second cut, but $\mathrm{Ni}$ concentrations increased in all individuals, whereas Co concentrations were lower than in the first harvest. In the Ni10Co100 treatment, the results were mixed; Ni increased at the second cut as well as Co in one individual, the other plant was too young at the time of the second cut. In the Ni100Co10 treatment, the age of the individuals was similar between the two cuts. For these, two categories of individuals were observed: (i) the individuals producing more biomass at the second cut but with a decrease in Ni concentration and (ii) the other ones for which growth was reduced but higher Ni concentration was obtained. Cobalt concentrations in this treatment were uniformly lower at second harvest. In the Ni100Co100 treatment, the biomass increased as well as the extraction of $\mathrm{Ni}$ and Co. For replicate \# 2 of the Ni100Co100 treatment, the quantities of extracted $\mathrm{Ni}$ and $\mathrm{Co}$ at the second cut were 8 and 10-fold higher than in the first cut, respectively. After 14 months of culture and two harvests, $B$. coddii had a potential yield that ranged from 4.96 to $9.30 \mathrm{t} \mathrm{ha}^{-1}$ (Table 4). With $10 \mathrm{mg} \mathrm{kg}^{-1}$ of added Ni in the substrate, B. coddii extracted $30.7 \%$ of the latter and $19.3 \%$ when the added concentration was $100 \mathrm{mg} \mathrm{kg}^{-1}$. When $100 \mathrm{mg}$ of Co were added per $\mathrm{kg}$ of substrate, B. coddii extracted about $6 \%$ of the Ni present, whatever the Ni content. Cobalt extracted was in the range of 3.31 to $5.22 \%$ if the spiked soil contained $>100 \mathrm{mg} \mathrm{kg}^{-1}$ of Co and $1.50 \%$ if the soil contained $>10 \mathrm{mg} \mathrm{kg}^{-1}$ of Co. Berkheya coddii can therefore extract $25 \mathrm{~kg}$ of $\mathrm{Ni} \mathrm{ha}{ }^{-1}$ in the presence of $\mathrm{Ni}$ and little Co, and 4.22 

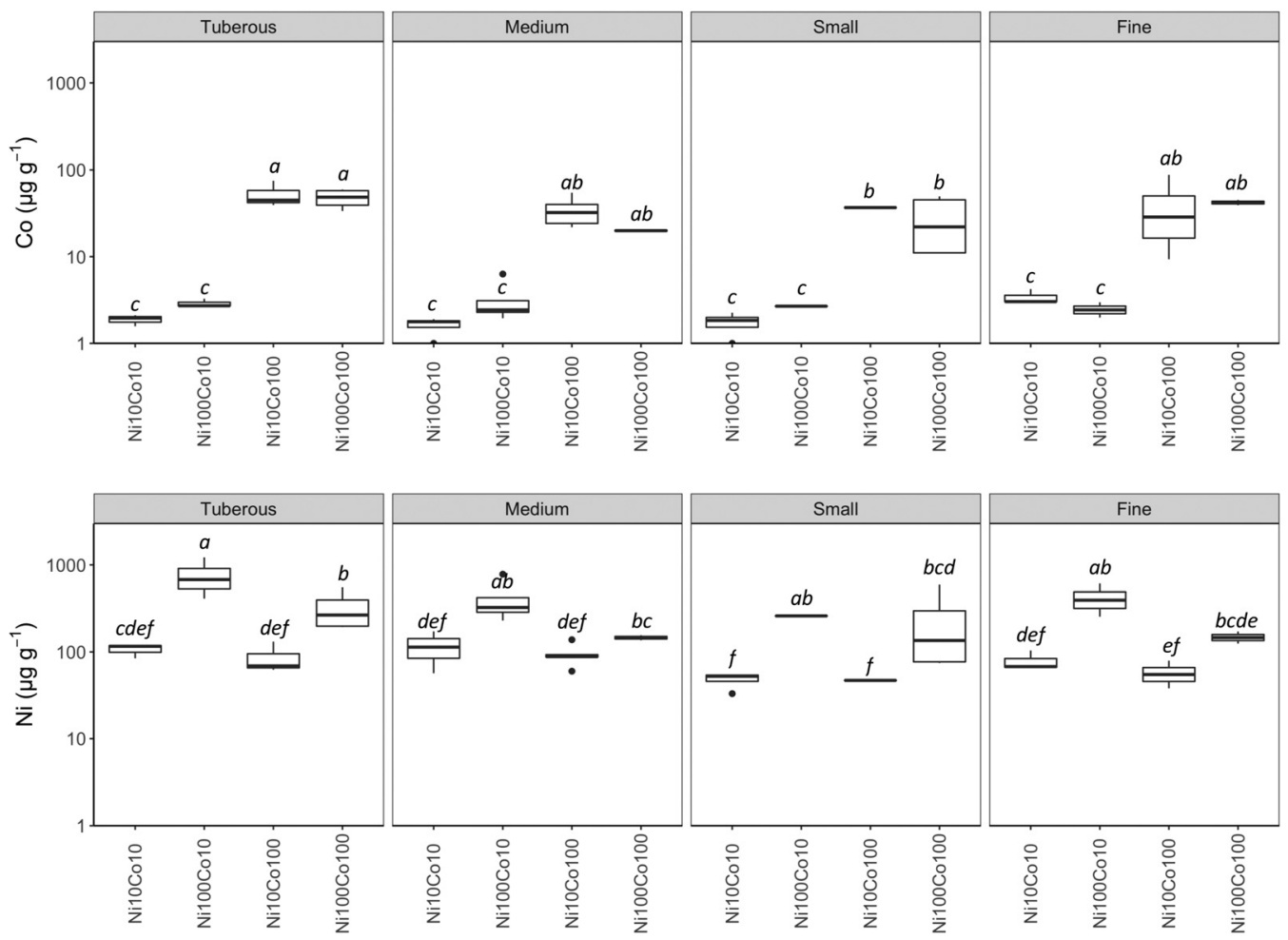

Fig. 4 Concentration of $\mathrm{Ni}$ and $\mathrm{Co}$ in the root parts of Berkheya coddii according to the $\mathrm{Ni}$ and Co concentrations in the substrate and the size of the root. T: tuber, M: medium roots, P: small roots, F: fine roots. Concentrations in $\mu \mathrm{g} \mathrm{g}^{-1}$.

Table 4 Potential yield of biomass and metal extracted by Berkheya coddii for 14 months on the four modalities, after two harvests (on a dry mass basis). Mean and (Min-Max). For each variable, the affected modalities of the same letter are not significantly different (Waller-Duncan means separation test, $p<0.05)$

\begin{tabular}{|c|c|c|c|c|c|c|c|c|c|c|}
\hline Treatment & Ni extracted \% & & Co extracted \% & & Biomass yield $t$ he & & Yield Ni kg ha ${ }^{-1}$ & & Yield Co kg ha ${ }^{-1}$ & \\
\hline Ni100Co10 & $19.3(16.9-21.0)$ & $a$ & $1.50(0.85-2.04)$ & $b$ & $6.39(3.88-7.75)$ & $a$ & $25.0(21.9-27.2)$ & $a$ & $0.19(0.11-0.26)$ & $b$ \\
\hline
\end{tabular}

to $6.65 \mathrm{~kg}$ of Co ha ${ }^{-1}$ in the presence of $\sim 100 \mathrm{mg}$ of Co in the substrate.

\section{Soil characteristics after plant culture}

Soil concentrations, $\mathrm{pH}$ and conductivity after plant culture are summarised in Table 5. Soil pH after plant culture was significantly lower in the Ni100Co100 treatment (5.62) compared to the Ni10Co10 (5.88) and Ni100Co10 treatments (5.83). Conductivity significantly increased during plant culture, from 86 to $209 \mu \mathrm{S} \mathrm{cm}{ }^{-1}$. The highest values were obtained in the
Ni100Co100 treatment (308 $\left.\mu \mathrm{S} \mathrm{cm}^{-1}\right)$ and the lowest in the Ni100Co10 treatment $\left(156 \mu \mathrm{S} \mathrm{cm}^{-1}\right)$. DTPA-extractable mean concentration of $\mathrm{Ni}$ and Co were $<5 \mathrm{mg} \mathrm{kg}^{-1}$ in the Ni10Co10 treatment. In the Ni100Co10 treatment, Ni was 50-fold higher than Co, which showed similar values with the Ni10Co10 treatment $\left(<1 \mathrm{mg} \mathrm{kg}^{-1}\right)$. In the Ni10Co100 and Ni100Co100 treatments, the differences in phytoavailable concentrations between the both elements were limited to 2.3 in Ni10Co100 treatment and 2.8 in Ni100Co100 with Co concentrations being statistically similar. The Ni phytoavailable concentrations in the

Table 5 Effect of Berkheya coddii plant 14-month growth on soil properties and phytoavailable Co/Ni concentrations according to the modality. Mean (Min-Max). For each variable, the affected modalities of the same letter are not significantly different (Waller-Duncan means separation test, $p<0.05$ )

\begin{tabular}{|c|c|c|c|c|c|c|c|c|}
\hline Treatment & $\mathrm{pH}$ & & CEC & & DTPA Co & & DTPA Ni & \\
\hline Ni10Co10 & $5.88(5.83-5.92)$ & $a$ & $191(161-218)$ & $a$ & $0.79(0.67-0.89)$ & $b$ & $4.57(4.09-5.48)$ & $d$ \\
\hline Ni100Co10 & $5.83(5.81-5.86)$ & $a$ & 156 (130-169) & $a$ & $0.73(0.70-0.75)$ & $b$ & $35.4(34.7-36.6)$ & $b$ \\
\hline Ni10Co100 & $5.76(5.61-5.74)$ & $a b$ & $270(174-382)$ & $a$ & $16.5(14.7-19.4)$ & $a$ & $7.30(6.8-7.6)$ & $c$ \\
\hline Ni100Co100 & $5.62(5.61-5.63)$ & $b$ & $308(232-444)$ & $a$ & $20.45(14.6-27.8)$ & $a$ & $54.1(39.2-69.3)$ & $a$ \\
\hline
\end{tabular}


Ni100Co100 treatment were significantly different at the end of experiment when compared to the other high $\mathrm{Ni}$ treatment despite being initially amended with identical concentrations. The transfer to plants is not responsible for this difference as the $\mathrm{Co}: \mathrm{Ni}$ is close to 1 .

\section{Discussion}

This study aimed to gain insights in the uptake and distribution in the different plant organs of both elements following Berkheya coddii phenology as no study focused on the Ni/Co interaction in Berkheya coddii mature plants. Therefore, $B$. coddii plants were grown for 14 months, which included a flowering that occurred approximatively 6-7 months after sowing, in pots containing an unfertilised neutral substrate, unlike ultramafic soils that are strongly Ni/Co imbalanced, spiked with different ratios of $\mathrm{Ni}$ and Co to compare the effect of the $\mathrm{Ni} / \mathrm{Co}$ ratio on metal uptake.

Symptoms of Co phytotoxicity (leaf greening inhibition) were observed in all treatments, but were more intense at the highest Co concentration used in this study $\left(\sim 120 \mathrm{mg} \mathrm{kg}^{-1}\right.$ total Co and $>500 \mu \mathrm{g} \mathrm{g}^{-1}$ Co in the plant). No other commonly observed symptoms (e.g. premature leaf closure or reduce leaf biomass) were found indicating either a mild Co phytotoxicity or that the higher Co concentration did not entirely caused the leaf greening inhibition. Cobalt phytotoxicity had previously been observed in 3-month-old $B$. coddii plants with a decrease of biomass at much lower concentration in the absence of $\mathrm{Ni}$ ( $\sim 40 \mathrm{mg} \mathrm{kg}^{-1}$ total Co in soil and $\sim 500 \mu \mathrm{g} \mathrm{g}^{-1}$ Co in the plant). In comparison, critical phytotoxicity symptoms including yellowing and brittleness of leaves as well as limited root development were observed at three times the maximum Co concentration used in this study again in absence of $\mathrm{Ni}$ $\left(\sim 300 \mathrm{mg} \mathrm{kg}^{-1}\right.$ total Co in soil and $\sim 1300 \mu \mathrm{g} \mathrm{g} \mathrm{g}^{-1}$ Co in the plant). ${ }^{32}$ On the other hand, and as expected based on observations in its natural South-African environment, $B$. coddii was more tolerant to high $\mathrm{Ni}$ concentration, whether in the substrate or internally. ${ }^{38}$

The distribution of $\mathrm{Ni}$ and $\mathrm{Co}$ in $B$. coddii was rather heterogeneous. In the aerial parts, there was no significant variation of $\mathrm{Ni}$ concentrations with leaf or stem age, contradicting past observations showing higher concentration in older leaves or the apical stem. ${ }^{46}$ The occurrence of higher concentrations in older leaves has not only been observed in B. coddii under experimental conditions in the past, as other $\mathrm{Ni}$ hyperaccumulator plants endemic displayed the same pattern in their natural environment, including Dichapetalum subsp. tuberculatum or Phyllanthus rufuschaneyi, both from Sabah. ${ }^{47,48}$ The difference observed in this study may be a consequence of the methodology used including the age at harvest, the growing media or the chosen modalities. In the inflorescence, $\mathrm{Ni}$ concentration progressively increased in the seeds during growth, whilst it decreased in the capitula, indicating a possible transfer from one to the other. Seed elemental chemistry is defined by genetic factors but varies based on environmental factors during seed development which leads ultimately to an extraordinary diversity among species, especially for transitions elements. ${ }^{49}$ The current state of knowledge on the storage and acquisition of metals in the seeds is limited because of the inherent difficulty in analysing elemental localisation in living tissue. However, newly developed system enabled the examination of the living while limiting radiation-induced damage. ${ }^{50,51}$ Investigation performed on $B$. coddii showed that $\mathrm{Ni}$ was predominantly present in the margins of the cotyledons, at the bottom of the embryo and in the micropylar. ${ }^{41}$

Cobalt concentrations were higher in the older leaves compared to the younger leaves in the low Co concentration substrate, but differences dimmed with higher Co concentration. In the presence of high concentrations of Co in the substrate, the entire leaf was affected by chlorosis, nevertheless, interveinal chlorosis was observed particularly in $B$. coddii basal leaves for all treatments, but the first signs of Co toxicity were seen at a concentration of $20 \mathrm{mg} \mathrm{kg}^{-1}$.

When observing the preference of $B$. coddii for either Co or $\mathrm{Ni}$ depending on the ratio of soil concentrations of the two elements, Ni was favoured at Ni:Co $(10: 10)$ treatment, but if the soil was spiked at $100 \mathrm{mg} \mathrm{kg}^{-1}$ for both metals, both were strongly extracted but ultimately at the advantage of Co as concentration of Co were $\sim 800 \mu \mathrm{g} \mathrm{g}^{-1}$ in the aerial parts, regardless of the concentration of $\mathrm{Ni}$ in the substrate (i.e. 10 or $100 \mathrm{mg} \mathrm{kg}^{-1}$ ). In the environment, Co tends to be more strongly retained than $\mathrm{Ni}$ to the solid phase of the soil and, therefore, less available to plants. ${ }^{34}$ However, increasing the total concentration of Co, especially through the addition of Co nitrate increases the readily available fraction significantly the substrate and leads to higher plant uptake. The increase in the concentration of $\mathrm{Ni}$ in the soil did not induce a similar increase in Ni uptake even though significant while the addition of Co significantly limited $\mathrm{Ni}$ uptake as a consequence of the competition existing between both elements. Antagonist interactions between $\mathrm{Co}$ and $\mathrm{Ni}$ have been demonstrated in $\mathrm{Co} / \mathrm{Ni}$ hyperaccumulator plants in favour of Co uptake. ${ }^{32,33}$

Nickel agromining is a specialised type of 'farming' of hyperaccumulator plants on ultramafic soils, whereby harvesting and incineration of the biomass to produce a high-grade 'bio-ore' from which Ni metals or pure salts can be recovered. ${ }^{12}$ Cobalt agromining is potentially profitable because of the metal's higher value compared to Ni 34.5 USD kg ${ }^{-1}$ against 13.5 USD for the metal in December 2019, but foliar Co accumulation is much lower than for Ni. B. coddii could surely be a good candidate for the decontamination of Ni-contaminated soils. Under improved agronomical practices, $B$. coddii may reach $22 \mathrm{t} \mathrm{ha}^{-1}$ of dry biomass, which assuming that soil characteristics are sufficient to reach the concentrations found in this study $\left(3490 \mathrm{mg} \mathrm{Ni} \mathrm{kg} \mathrm{kg}^{-1}\right.$ or $742 \mathrm{mg} \mathrm{Co} \mathrm{kg}^{-1}$ ) when cultivated as a crop, B. coddii could

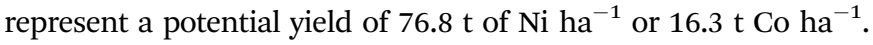
For $\mathrm{Ni}$, the quantities extracted would be comparable to those obtained in the field with other studied species, while Co, on the other hand, they are too low for economic reasons. However, with the development of appropriate agronomical system to control both plant uptakes but also soil chemistry that deeply change in 
the experiment (fertilisation, crop density, liming...), Co yield may increase and reach economic viability. ${ }^{52,53}$ At this stage, the numbers are only orders of magnitude, since cultivation on real soil and a larger scale is very different from that on amended soil in pot. Indeed, yields depend on many conditions (soil fertility, fertilisation, watering, etc.). ${ }^{54}$ Additional positive points, not yet discussed, about potential agromining operations were revealed by this study, such as the possibility to have two harvests per year in controlled environments or the fact that $B$. coddii develops perennial tubers which can be reused from one year to the next by leaving them in place or harvesting them for use on other substrates. Finally, it is hoped that this study will promote interest in $B$. coddii and its potential to be used in large-scale economically viable agromining operations.

\section{Conflicts of interest}

There are no conflicts to declare.

\section{Acknowledgements}

This work was supported by French National Research Funding Agency (ANR), via the research program AGROMINE, ANR-14CE04-0005. We thank the GISFI project and we would like to thank Stéphane Colin for the implementation of experimental design, Lucas Charrois and Jean Claude Begin for the preparation of the samples and Romain Goudon for his help with the ICP-AES analysis. Dr Robin Dagois and Dr Charlotte Berthelot for their help for the harvesting the plants in the pots. We also extend our thanks to Professor Alan Baker (Universities of Melbourne and Queensland, Australia) for advice and improvement of the text.

\section{References}

1 T. Jaffré, R. R. Brooks, J. Lee and R. D. Reeves, Sebertia acuminata: A hyperaccumulator of nickel from New Caledonia, Science, 1976, 193, 579-580, DOI: 10.1126/science.193.4253.579.

2 A. J. M. Baker and R. R. Brooks, Terrestrial higher plants which hyperaccumulate metallic elements: a review of their distribution, ecology and phytochemistry, Biorecovery, 1989, 1, 81-126, DOI: 10.1080/01904168109362867.

3 R. D. Reeves, Tropical hyperaccumulators of metals and their potential for phytoextraction, Plant Soil, 2003, 249, 57-65, DOI: 10.1023/A:1022572517197.

4 A. van der Ent, A. J. M. Baker, R. D. Reeves, A. J. Pollard and H. Schat, Hyperaccumulators of metal and metalloid trace elements: Facts and fiction, Plant Soil, 2012, 362, 319-334, DOI: $10.1007 / \mathrm{s} 11104-012-1287-3$.

5 A. J. Pollard, K. D. Powell, F. A. Harper and J. A. C. Smith, The genetic basis of metal hyperaccumulation in plants, Crit. Rev. Plant Sci., 2002, 21, 539-566, DOI: 10.1080/0735260291044359.

6 B. H. Robinson, R. R. Brooks, A. W. Howes, J. H. Kirkman and P. E. Gregg, The potential of the high-biomass nickel hyperaccumulator Berkheya coddii for phytoremediation and phytomining, J. Geochem. Explor., 1997, 60, 115-126, DOI: 10.1016/S0375-6742(97)00036-8.

7 B. H. Robinson, A. Chiarucci, R. R. Brooks, D. Petit, J. H. Kirkman, P. E. Gregg and V. De Dominicis, The nickel hyperaccumulator plant Alyssum bertolonii as a potential agent for phytoremediation and phytomining of nickel, J. Geochem. Explor., 1997, 59, 75-86, DOI: 10.1016/S03756742(97)00010-1.

8 R. L. Chaney, J. S. Angle, A. J. M. Baker and Y.-M. Li, US Pat., 5711784, 1998.

9 J. S. Angle, E. Brewer, R. L. Chaney, J. Nelkin, V. Volk, A. J. M. Baker, S. Burke, R. Roseberg, Y. Li and R. Reeves, Developing commercial phytoextraction technologies: practical considerations, S. Afr. J. Sci., 2001, 97, 619-623, DOI: 10520/EJC97231.

10 Y.-M. Li, R. Chaney, E. Brewer, R. Roseberg, J. S. Angle, A. J. M. Baker, R. Reeves and J. Nelkin, Development of a technology for commercial phytoextraction of nickel: Economic and technical considerations, Plant Soil, 2003, 249, 107-115, DOI: 10.1023/A:1022527330401.

11 Using plants to "micro-mine" metals. http://www.inra.fr/en/ Scientists-Students/Biomass/All-the-news/Using-plants-tomicro-mine-metals, accessed April 2017.

12 A. van der Ent, A. J. M. Baker, R. D. Reeves, R. L. Chaney, C. W. Anderson, J. A. Meech, P. D. Erskine, M.-O. Simonnot, J. Vaughan, J. L. Morel and G. Echevarria, Agromining: Farming for metals in the future?, Environ. Sci. Technol., 2015, 49, 4773-4780, DOI: 10.1021/es506031u.

13 R. L. Chaney, J. S. Angle, C. L. Broadhurst, C. A. Peters, R. V. Tappero and D. L. Sparks, Improved understanding of hyperaccumulation yields commercial phytoextraction and phytomining technologies, J. Environ. Qual., 2007, 36, 1429-1443, DOI: 10.2134/jeq2006.0514.

14 P. N. Nkrumah, A. J. M. Baker, R. L. Chaney, P. D. Erskine, G. Echevarria, J. L. Morel and A. van der Ent, Current status and challenges in developing nickel phytomining: an agronomic perspective, Plant Soil, 2016, 406, 55-69, DOI: 10.1007/s11104-016-2859-4.

15 J. Rodrigues, V. Houzelot, F. Ferrari, G. Echevarria, B. Laubie, J. L. Morel, M.-O. Simonnot and M.-N. Pons, Life cycle assessment of agromining chain highlights role of erosion control and bioenergy, J. Clean. Prod., 2016, 139, 770-778, DOI: 10.1016/j.jclepro.2016.08.110.

16 M.-N. Pons, J. Rodrigues and M.-O. Simonnot, Life Cycle Assessment and Ecosystem Services of Agromining, in Agromining: Farming for Metals: Extracting Unconventional Resources Using Plants, ed. A. van der Ent, G. Echevarria, A. J. M. Baker and J. L. Morel, Springer International Publishing, Cham, 2018, pp. 53-73, DOI: 10.1007/978-3319-61899-9_4.

17 G. Echevarria, Genesis and behaviour of ultramafic soils and consequences for nickel biogeochemistry, in Agromining: farming for metals, ed. A. van der Ent, G. Echevarria and J. L. Morel, Springer, Cham, 2017, pp. 135-156, DOI: 10.1007/ 978-3-319-61899-9_8. 
18 J. O. Mesjasz-Przybylowicz, W. J. Przybylowicz, A. D. Barnabas and A. van der Ent, Extreme nickel hyperaccumulation in the vascular tracts of the tree Phyllanthus balgooyi from Borneo, New Phytol., 2016, 209, 1513-1526, DOI: 10.1111/nph.13712.

19 A. van der Ent, D. L. Callahan, B. N. Noller, J. O. MesjaszPrzybylowicz, W. J. Przybylowicz, A. D. Barnabas and H. H. Harris, Nickel biopathways in tropical nickel hyperaccumulating trees from Sabah (Malaysia), Sci. Rep., 2017, 7, 41861, DOI: 10.1038/srep41861.

20 A. van der Ent, R. Mak, M. D. de Jonge and H. H. Harris, Simultaneous hyperaccumulation of nickel and cobalt in the tree Glochidion cf. sericeum (Phyllanthaceae): elemental distribution and chemical speciation, Sci. Rep., 2018, 26, 1-5, DOI: 10.1038/s41598-018-26891-7.

21 R. R. Brooks, J. Lee, R. D. Reeves and T. Jaffré, Detection of nickeliferous rocks by analysis of herbarium specimens of indicator plants, J. Geochem. Explor., 1977, 7, 49-57, DOI: 10.1016/0375-6742(77)90074-7.

22 U. Krämer, Metal hyperaccumulation in plants, Annu. Rev. Plant Biol., 2010, 61, 517-534, DOI: 10.1146/annurevarplant-042809-112156.

23 R. R. Brooks, R. D. Reeves, R. S. Morrison and F. Malaisse, Hyperaccumulation of copper and cobalt - A review, Bull. Soc. R. Bot. Belg., 1980, 113, 166-172.

24 R. D. Reeves, A. J. M. Baker, T. Jaffré, P. D. Erskine, G. Echevarria and A. van der Ent, A global database for plants that hyperaccumulate metal and metalloid trace elements, New Phytol., 2018, 218, 407-411, DOI: 10.1111/ nph.14907.

25 A. van der Ent, F. Malaisse, P. D. Erskine, J. O. MesjaszPrzybyłowicz, W. J. Przybyłowicz, A. D. Barnabas, M. Sośnicka and H. H. Harris, Abnormal concentrations of $\mathrm{Cu}-\mathrm{Co}$ in Haumaniastrum katangense, Haumaniastrum robertii and Aeolanthus biformifolius: contamination or hyperaccumulation?, Metallomics, 2019, 11, 586-596, DOI: 10.1039/ C8MT00300A.

26 R. R. Brooks, E. D. Wither and B. Zepernick, Cobalt and nickel in Rinorea species, Plant Soil, 1977, 47, 707-712, DOI: 10.1007/BF00011041.

27 F. A. Homer, R. S. Morrison, R. R. Brooks, J. Clemens and R. D. Reeves, Comparative studies of nickel, cobalt, and copper uptake by some nickel hyperaccumulators of the genus Alyssum, Plant Soil, 1991, 138, 195-205, DOI: 10.1007/ BF00012246.

28 D. R. Morrey, K. Balkwill and M.-J. Balkwill, Studies on serpentine flora: preliminary analyses of soils and vegetation associated with serpentinite rock formations in the South-Eastern Transvaal, S. Afr. J. Bot., 1989, 55, 171-177, DOI: 10.1016/S0254-6299(16)31203-0.

29 A. Bani, G. Echevarria, S. Sulçe, J. L. Morel and A. Mullai, In situ phytoextraction of $\mathrm{Ni}$ by a native population of Alyssum murale on an ultramafic site (Albania), Plant Soil, 2007, 293, 79-89, DOI: 10.1007/s11104-007-9245-1.

30 S. Albanese, M. Sadeghi, A. Lima, D. Cicchella, E. Dinelli, P. Valera, M. Falconi, A. Demetriades and B. De Vivo, and The GEMAS Project Team, GEMAS: cobalt, $\mathrm{Cr}, \mathrm{Cu}$ and $\mathrm{Ni}$ distribution in agricultural and grazing land soil of Europe, J. Geochem. Explor., 2015, 154, 81-93, DOI: 10.1016/ j.gexplo.2015.01.004.

31 M. Malik, R. L. Chaney, E. P. Brewer, Y.-M. Li and J. S. Angle, Phytoextraction of soil cobalt using hyperaccumulator plants, Int. J. Phytorem., 2000, 2, 319-329, DOI: 10.1080/ 15226510008500041.

32 S. M. Keeling, R. B. Stewart, C. W. N. Anderson and B. H. Robinson, Nickel and Cobalt Phytoextraction by the Hyperaccumulator Berkheya coddii: Implications for Polymetallic Phytomining and Phytoremediation, Int. J. Phytorem., 2003, 5, 235-244, DOI: 10.1080/713779223.

33 R. Tappero, E. Peltier, M. Gräfe, K. Heidel, M. Ginder-Vogel, K. J. Livi, M. L. Rivers, M. A. Marcus, R. L. Chaney and D. L. Sparks, Hyperaccumulator Alyssum murale relies on a different metal storage mechanism for cobalt than for nickel, New Phytol., 2007, 175, 641-654, DOI: 10.1111/ j.1469-8137.2007.02134.x.

34 B. Lange, A. van der Ent, A. J. M. Baker, G. Echevarria, G. Mahy, F. Malaisse, P. Meerts, O. Pourret, N. Verbruggen and M. P. Faucon, Copper and cobalt accumulation in plants: a critical assessment of the current state of knowledge, New Phytol., 2017, 213, 537-551, DOI: 10.1111/nph.14175.

35 Y.-M. Li, R. L. Chaney, E. P. Brewer, J. S. Angle and J. Nelkin, Phytoextraction of nickel and cobalt by hyperaccumulator Alyssum species grown on nickel contaminated soils, Environ. Sci. Technol., 2003, 37, 1463-1468, DOI: 10.1021/es0208963.

36 U. Kukier, C. A. Peters, R. L. Chaney, J. S. Angle and R. J. Roseberg, The effect of $\mathrm{pH}$ on metal accumulation in two Alyssum species, J. Environ. Qual., 2004, 33, 2090-2102, DOI: $10.2134 /$ jeq2004.2090.

37 D. R. Morrey, K. Balkwill, M.-J. Balkwill and S. Williamson, A review of some studies of the serpentine flora of southern Africa, ed. A. J. M. Baker, J. Proctor and R. D. Reeves, The vegetation of ultramafic (serpentine) soil, Intercept, Andover, 1992, pp. 147-157.

38 T. R. Anderson, A. W. Howes, K. Slatter and M. F. Dutton, Studies on the nickel hyperaccumulator, Berkheya coddii, ed. T. Jaffré, R. D. Reeves, T. Becquer, The ecology of ultramafic and metalliferous areas, Proceedings of the Second International Conference on Serpentine Ecology, Nouméa, 1997, pp. 2261-2266.

39 S. Smith, K. Balkwill and S. Williamson, Compositae on serpentine in the Barberton Greenstone Belt, South Africa, S. Afr. J. Sci., 2001, 97, 518-520, DOI: 10520/EJC97256.

40 J. O. Mesjasz-Przybyłowicz, M. I. Nakonieczny, P. A. Migula, M. A. Augustyniak, M. O. Tarnawska, W. U. Reimold, C. H. Koeberl, W. J. Przybyłowicz and E. L. Głowacka, Uptake of cadmium, lead nickel and zinc from soil and water solutions by the nickel hyperaccumulator Berkheya coddii, Acta Biol. Cracov., Ser. Bot., 2004, 46, 75-85.

41 J. O. Mesjasz-Przybylowicz and W. J. Przybylowicz, Nickel distribution in Berkheya coddii leaves by micro-PIXE and SEM/EDS, Proc. - Microsc. Soc. South Afr., 2003, 33, 68.

42 E. Orłowska, J. O. Mesjasz-Przybyłowicz, W. J. Przybyłowicz and K. Turnau, Nuclear microprobe studies of elemental 
distribution in mycorrhizal and non-mycorrhizal roots of Ni-hyperaccumulator Berkheya coddii, X-Ray Spectrom., 2008, 37, 129-132, DOI: 10.1002/xrs.1034.

43 S. Groeber, W. J. Przybylowicz, G. Echevarria, E. MontargesPelletier, A. D. Barnabas and J. O. Mesjasz-Przybyłowicz, Fate of nickel and calcium in seedlings of the hyperaccumulator Berkheya coddii during germination, Biol. Plant., 2015, 59, 560-569, DOI: 10.1007/s10535-015-0527-9.

44 A. van der Ent, P. N. Nkrumah, M. Tibbett and G. Echevarria, Evaluating soil extraction methods for chemical characterization of ultramafic soils in Kinabalu Park (Malaysia), J. Geochem. Explor., 2019, 196, 235-246, DOI: 10.1016/ j.gexplo.2018.10.004.

45 G. L. Long and J. D. Winefordner, Limit of detection. A closer look at the IUPAC definition, Anal. Chem., 1983, 55, 712-724, DOI: 10.1021/ac00258a724.

46 B. H. Robinson, E. Lombi, F. J. Zhao and S. P. McGrath, Uptake and distribution of nickel and other metals in the hyperaccumulator Berkheya coddii, New Phytol., 2003, 158, 279-285, DOI: 10.1046/j.1469-8137.2003.00743.x.

47 R. Bouman, P. van Welzen, S. Sumail, G. Echevarria, P. D. Erskine and A. van der Ent, Phyllanthus rufuschaneyi: a new nickel hyperaccumulator from Sabah (Borneo Island) with potential for tropical agromining, Bot. Stud., 2018, 59, 9, DOI: 10.1186/s40529-018-0225-y.

48 P. N. Nkrumah, G. Echevarria, P. D. Erskine and A. van der Ent, A, Contrasting nickel and zinc hyperaccumulation in subspecies of Dichapetalum gelonioides from Southeast Asia, Sci. Rep., 2018, 8, 1-5, DOI: 10.1038/s41598-018-26859-7.

49 J. D. Bewley and M. Black, Seeds, Springer, Boston, 1994, DOI: 10.1007/978-1-4899-1002-8.

50 P. M. Kopittke, T. Punshon, D. J. Paterson, R. V. Tappero, P. Wang, F. P. Blamey, A. van der Ent and E. Lombi, Synchrotron- based X-ray fluorescence microscopy as a technique for imaging of elements in plants, Plant Physiol., 2018, 178, 507-523, DOI: 10.1104/pp.18.00759.

51 A. van der Ent, W. J. Przybyłowicz, M. D. de Jonge, H. H. Harris, C. G. Ryan, G. Tylko, D. J. Paterson, A. D. Barnabas, P. M. Kopittke and J. O. Mesjasz-Przybyłowicz, $\mathrm{X}$-ray elemental mapping techniques for elucidating the ecophysiology of hyperaccumulator plants, New Phytol., 2018, 218, 432-452, DOI: 10.1111/nph.14810.

52 A. Bani, G. Echevarria, S. Sulçe and J. L. Morel, Improving the Agronomy of Alyssum murale for Extensive Phytomining: A Five-Year Field Study, Int. J. Phytorem., 2014, 17, 117-127, DOI: 10.1080/15226514.2013.862204.

53 T. Rosenkranz, C. Hipfinger, C. Ridard and M. Puschenreiter, A nickel phytomining field trial using Odontarrhena chalcidica and Noccaea goesingensis on an Austrian serpentine soil, J. Environ. Manage., 2019, 242, 522-528, DOI: 10.1016/ j.jenvman.2019.04.073.

54 M. P. C. de Vries, How reliable are results of pot experiments?, Commun. Soil Sci. Plant Anal., 1980, 11, 895-902, DOI: 10.1080/ 00103628009367090. 